\title{
Regional Indicators of the Safety Development of the Entrepreneurship Economy
}

\author{
Elena Ivleva ${ }^{1, *}$, Khe Sun $\mathrm{Pak}^{1}$, and Ksenia Nagornaya ${ }^{1}$ \\ ${ }^{1}$ Saint-Petersburg Academic University, 190103 Lermontovsky pr. 44, Saint-Petersburg, Russia
}

\begin{abstract}
The present article is dedicated to identification of opportunities for stating and solving research problems related to evaluation of social and - economic development safety and efficient use of the regional economic potential. The analytical base is the statistical information for the North - West Federal District (NWFD) of Russian Federation. The authors offer the system of indicators of development safety and effective use of the economic potential. Each of them can be calculated individually for the territory. In practical terms, these indicators can be used by the executive authorities and regional administration to monitor changes.
\end{abstract}

\section{Introduction}

The importance and suspense of some economic, social and environmental issues makes the study of the whole set of issues related to the regional development safety management vitally important. The development of the management mechanism involves the development of assessment tools to measure the territory development safety, quantitative and qualitative indicators that allow researchers to draw conclusions and make the practical person take administrative decisions, considering the territory potential. Thus, the problem is not only of the theoretical but also of the practical interest. The system of indicators is offered to assess the social and economic development safety and effective use of the economic potential. This system can be used by the executive bodies of the Russian Federation territorial units to conduct the monitoring researches. The system of indicators shall be supplemented by ecological development indicators of the territories, as an approach from the standpoint of sustainability implies the solution of problems of social, ecological and economic character [1-23].

\section{Theory}

Regional safety is the main dominant of the territory sustainable development. The possibility to achieve sustainable development including at least clean technologies, ecofriendly products and use of sustainable resource, seems to be fairly remote. [1] This can be proven by facts. Let us pay attention at least to the following three of them:

*Corresponding author: ivlevaes@mail.ru 
1. Opposite trends of economic and environmental cycles.

2. Mismatch of factors that determine economic and ecological components of sustainable economic growth, including the regional one.

3. Economic and ecological subsystems being developed in different directions, destabilizing the entire economic system.

This is the reality in which management decisions that determine the quality of life tomorrow are taken today.

In matters of sustainable development everything is controversial: theoretical feasibility, methodological argumentation, methodological support. The authors consider that the economic system does not aspire to a stability condition. This point of view is supported by the cycle theory [2]. Interrelation of development and safety is confirmed in the research papers of many authors, including ones of A. D. Ursul and A.L. Romanovich [3] and American scientist George Kirschner [4].

\section{Results}

The system of indicators is determined to assess not only the approach of the individual territorial development path to the level of safety, but also the effectiveness of managing this process on the principles of sociological, ecological and economic balance. To assess the level of social and economic safety of territories the system of 14 indicators is used (see. Table 1). It is necessary to explain the indicator stating "the ratio of financial assistance to the region from the federal budget to the volume of federal budget revenues received from the region." The latter is represented by a different phrasing due to the lack of information: the ratio of financial assistance to the region from the federal budget to the volume of revenues of the regional budget. The overall list of indicators includes also the innovative development index, introduced by the Institute for Statistical Studies and Economics of Knowledge of "Higher School of Economics", that reflects the level of scientific potential, social and economic status, openness of the government, and other indicators of the territorial units of the Russian Federation. The average median index of groups characterized by average, maximum and minimum figures for the period under review represents the threshold. The system of indicators presented in the article by I.E. Denezhkina, D. Suzdaleva [6] was used when preparing indicators to measure the economic safety of the regional development. Figures presented in the Moscow Government Decree № 707-RP "About approval of the Concept of complex safety of the city of Moscow”" [11] as of April 16th, 2010 can be used as basic indicators to measure the social safety of the regional development. These indicators include the following ones: the ratio of expenditures on social programs to the gross regional product (GRP), the ratio of incomes between the richest $10 \%$ and the poorest $10 \%$ of population groups, the proportion of the population below the poverty threshold, the ratio of minimum and average salaries, the crime rate (number of crimes per 100 thousand of population), the population life expectancy, the level of the population distrust to the authorities. We consider it important to add the following indicator to the proposed ones: "The amount of damage caused to the society as a result of corrupt activities of state and municipal employees." According to Rosstat (the Federal State Statistics Service), within the last few years there were significant changes in the structure of the layer of the richest: the share of wealthy officials (that determine the redistribution of wealth) rose, forcing out business people and professionals.

It is widely known that the multi-criteria assessment of safety includes the assessment of the economic potential of the region and determination of potential use effectiveness. The economic potential determines the material base for safe development of the territory. The search for reserves by the main factors affecting the level of regional safety is carried 
out to determine the effectiveness of the territory economic potential use. The following parameters are used for assessment: return on investment (the ratio of GRP to investment in the fixed capital), return on taxes (the ratio of tax revenues from the territory to the volume of GRP), return on assets, profitability of fixed assets, productivity, capital-labor ratio, return on wages and return on amortization [13].

Selection of indicators for assessment of the social and economic safety of the regional development in the North-West Federal District in 2013 is represented in the Table 1. It was used for the first time in the article [14].

St.Petersburg can be highlighted by the highest GDP per capita in comparison with the world average of $41 \%$ (the highest level of this indicator in the world as of 2013 is in Luxembourg - 6,091,568 rubles). The lowest indicator is in the Pskov region (2.7\%).

The highest capital consumption level is registered in the Komi Republic $(46.2 \%)$. The lowest value for this indicator is, however, registered in the Leningrad Region (32.4\%) as this region has been characterized by the high level of investment activity for many years. The capital consumption figure in all districts of this region is below the threshold value.

In terms of the ratio of investment to GRP the Komi Republic stands out from the other regions $-40.6 \%$. The mining industry, wood processing industry, chemical industry and mechanical engineering have contributed to these results. As of 2013 by this indicator the Komi Republic outperformed the Leningrad Region that had been the leader in this field for years. The lowest rate of this indicator is determined in Saint - Petersburg (19\%) and the Republic of Karelia (19.4\%) [10]. These values are below the threshold.

Saint - Petersburg belongs to the group of regions with high innovation activity (0.5382). The lowest index is in the Pskov Region - 0.2324. The Pskov Region belongs to the group of regions with moderate innovative activity [5].

The lowest unemployment rate is observed in Saint - Petersburg - 1.5\%, while the highest is in the Komi Republic -7.1. In recent years there has been a significant decrease of employment in the electricity, coal (closure and liquidation of unprofitable mines) and gas industries, the pulp and paper industry and other industries. The unemployment rate in all other regions is well below the threshold.

The volume of the federal budget financial assistance to Saint - Petersburg accounts for $0.07 \%$ of the regional budget income - the factor indicates financial independence of the city from the center. It is the lowest rate in the district, while the highest one $(0,41 \%)$ is in the Pskov Region. Evidently this region has a high level of a debt burden $-72.4 \%$. In our opinion, in parallel with the indicator "ratio of financial assistance from the federal budget to the region to the volume of the regional budget revenues») we need to use another indicator - the amount of the debt burden. The level of a debt burden of the district regions is the highest in the Republic of Karelia - 96,3\% [8]. They are equal to own revenues and financial assistance from the federal budget accounts for $34 \%$.

The ratio of expenditures on social programs to the GRP is the highest in the Arkhangelsk Region - 32.5\%, exceeding the threshold value (20\%). The share of social expenditures of the regional consolidated budget compounds $67 \%$ in the general amount of expenditures, the level of a debt burden in the region is $62 \%$, the volume of the federal budget financial assistance is $23 \%$ of the regional budget income. This situation will necessarily lead to reduction not only in non-social expenditures, but also in expenditures on social programs. The value of this indicator for other regions of the district doesn't not exceed the threshold.

The ratio of incomes of $10 \%$ of the richest population groups and $10 \%$ of the poorest population groups in all regions of the district exceeds a threshold value (10:1); the highest ratio is in St. - Petersburg (20.2: 1), in Russia (16.8: 1). "By the ratio of revenues to be distributed between the poorest and the richest, we have already passed the threshold of social safety", - says Jacob Dubenetsky, the Head of Investment Centre of the Institute of 
Economic Forecasting. The share of the population living in poverty in all regions of the district exceeds the threshold value, with the exception of Saint - Petersburg (8.3\%). A very high percentage of the poor is in the Pskov Region (16.9\%). The region has a high level of a debt burden, the lowest index of innovative development and the volume of GRP per capita.

The ratio of minimum and average wages in all the territorial units of the Russian Federation exceeds the threshold value (1:3), the highest proportion is observed in the Komi Republic and Arkhangelsk Region that have the same value (1: 6). According to the data, the average salary in the Republic covers 4.2 minimum levels of subsistence, in the region -2.9 minimum levels of subsistence.

The crime rate in all regions of the district is below the threshold (5-6 thousand per 100 thousand of inhabitants). The high crime rate is observed in the Komi Republic $(2,377$ thousand per 100 thousand of inhabitants). In the Republic there is the highest ratio of minimum and average wages. The level of capital consumption and the share of the population living below the poverty line exceeds the threshold of safety. The lowest rate is observed in Saint - Petersburg and the Leningrad Region - 1,100 and 1,105 thousand per 100 thousand inhabitants, respectively. In Russia this indicator is 1,476 thousand per 100 thousand inhabitants. The life expectancy rate of the population in all territorial units of the Russian Federation exceeds the lower limit of the threshold value. The lowest life expectancy rate is observed in the Pskov Region (67,2 years).

The level of public distrust to the authorities is very high in the Kaliningrad Region (79\%), the Republic of Karelia (77\%) and the Novgorod Region (82\%). Only in three regions - Saint - Petersburg (17\%), the Pskov Region (17\%), and the Vologda Region $(24 \%)$ this indicator is below the threshold value $(20-25 \%)$. In other regions the level of public distrust to the authorities is high (from 46 to $66 \%$ ). The reasons are as follows: the low level of activity and effectiveness of the regional policy, poor implementation of demographic, social and family programs, poor quality of medical services (new technologies and equipment are not introduced, no kind of activity is led to achieve an accessible and quality health care in remote areas), few measures are taken to meet the cultural needs of the population [7].

The results are as follows:

1. There is a drop of the industrial production level not only in weak regions, but in the most developed ones, for example, in St. Petersburg $-8.2 \%$.

2. A high degree of capital consumption is confirmed.

3. The investment activity of the regions is being reduced.

4. The debt burden of the regions increases.

5. By the level of capital consumption and the ratio of minimum and average wages, all territorial units of the Russian Federation passed the threshold of social safety.

6 . The level of public distrust to the authorities is still very high.

Let us determine the task as follows: search of reserves and assessment of use of the regional economies potential.

Enhancement potential of the social and economic safety level of the regional development is determined by evaluating the effectiveness of the economic potential use by the indicators presented in Table. 2.

The highest returns on investment, the ratio of GRP to investments in fixed assets, are observed in St. Petersburg. The region executes major investment projects for construction of the central section of the road Western High-Speed Diameter and integrated development of the subway in the amount of 73 billion rubles. The volume of investments into development of the pharmaceutical cluster is 21.7 billion rubles. [9]. The lowest return on assets is in the Arkhangelsk Region, where in recent years there has been decrease in total amount of investments. 
The leader in the return on assets (1.05 rub.) is the Kaliningrad Region. Every year fixed assets are renewed in the region. The outsider by this indicator is the Murmansk Region ( 0.21 rub.), where the degree of capital consumption in 2013 increased by $26 \%$ in comparison with 2012.

By the profitability of fixed assets the most advance region tends to be St. Petersburg $(8.7 \%)$ with the highest capital productivity. The same cannot be said about the Pskov Region $(0.77 \%)$, where the return on assets is the lowest. In the region there is the lowest volume of investment into fixed assets per capita among the territorial units of the Russian Federation.

The high capital-labor ratio remarks the Komi Republic $(4.35 \%)$, which is one of the three regions of the Russian Federation with the largest volume of investments. The low capital-labor ratio is in the Kaliningrad Region (0.55\%).

The largest amount of tax revenues from each ruble of GRP (returns on tax) is registered in the Komi Republic (24.51 kopecks), the lowest - in the Arkhangelsk Region (8.69 kopecks). With almost the same volume of GRP the amount of tax revenues in the Komi Republic is 3 times more than in the Arkhangelsk Region.

The Komi Republic is the leader in the efficient use of the territory economic potential; it has the highest labor productivity $-1.1 \mathrm{mln}$. rubles per person employed in the economic sector, the lowest one is in the Pskov Region - 0.35 million. rub. The latter belongs to the group of regions with the lowest rating by the social and economic status.

By the return on wages the Komi Republic (2.44 rub.) lags slightly from the leader by this indicator - the Leningrad Region (2.62 rub.), the lowest rate is in the Pskov Region (1.48 rub.).

The return on amortization in the Kaliningrad Region is the highest among the regions of the district -3.02 rubles. The region belongs to the group of regions with the lowest level of capital consumption. The return on amortization in the Murmansk Region ( $0.55 \mathrm{rub}$.)and in the Komi Republic (0.54 rub.) is the lowest among the territorial units of the Russian Federation. They belong to the group of "regions with a high degree of capital consumption".

In general, by the efficient use of the territory economic potential the regions of the district demonstrate satisfactory results, especially the Republic of Komi, the Leningrad Region, the Kaliningrad Region and Saint - Petersburg. In these and other regions there is sufficient potential to improve the level of social and economic safety of the territory. Even the Pskov Region has significant potential: high transport capacity, good prospects for development of the energy infrastructure with connection to the largest sources of energy, development of customs and logistics terminals at the international checkpoints of the state border of the Russian Federation [9].

\section{Conclusions}

1. Monitoring studies must include the indicators of the territory development safety. The existing system of indicators to measure the quality of life, the level of social and economic development and the efficiency of public administration does not consider the basic parameters of the social safety.

2. To assess the efficiency of the social and economic safety management of development of the regions it seems appropriate to use structural indicators. They demonstrate constraints for the innovative growth and contradictory dynamics that not always can be explained from the standpoint of production. The indicators help to identify the factors destabilizing economic development and denying principles of sustainable development. 
3. To illustrate a sustainable outcome of the study it is necessary to introduce a number of environmental indicators, including structural ones, such as the dynamics of all types of pollution, dynamics of production and consumption waste as a whole and per capita, and others.

4. It should be stated that the existing system of indicators to measure the quality of life, the level of social and economic development, and the effectiveness of government management almost doesn't take into account innovative components. We used the index of innovative development.

Table 1. Level of social and economic safety of the region.

\begin{tabular}{|c|c|c|c|c|c|c|c|c|c|c|c|c|}
\hline \multirow[b]{2}{*}{ 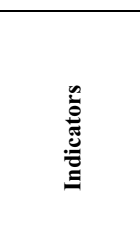 } & \multirow[b]{2}{*}{ 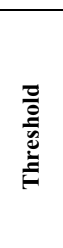 } & \multicolumn{11}{|c|}{ Actual value } \\
\hline & & 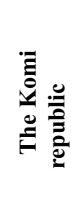 & 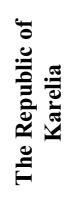 & 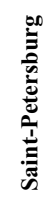 & 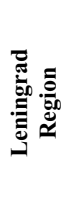 & 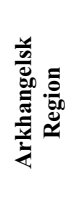 & 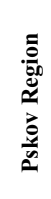 & 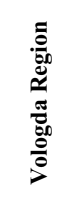 & 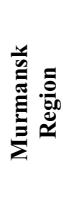 & 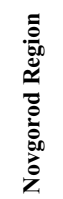 & 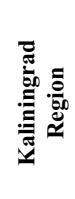 & 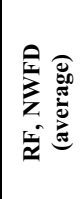 \\
\hline 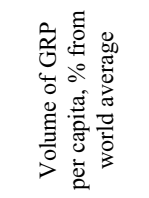 & 100 & 8.65 & 4.5 & 41 & 6.5 & 6.4 & 2.7 & 4.9 & 5.9 & 4.5 & 4.6 & $\begin{array}{l}\hat{a} \\
\infty \\
1 \\
1 \\
1 \\
\vdots \\
z\end{array}$ \\
\hline 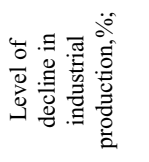 & $\begin{array}{c}30- \\
40\end{array}$ & 100.7 & $\begin{array}{c}100 \\
.3\end{array}$ & 91.8 & $\begin{array}{c}100 . \\
1\end{array}$ & 108.3 & 94.0 & 105.6 & 97.8 & $\begin{array}{c}109 . \\
2\end{array}$ & 108.7 & 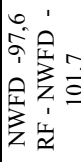 \\
\hline 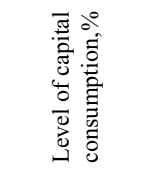 & 60 & 46.2 & $\begin{array}{c}43 . \\
4\end{array}$ & 36.8 & 32.4 & 41 & 40.4 & 43.1 & 39.5 & 43.8 & 34.7 & 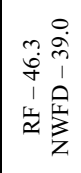 \\
\hline 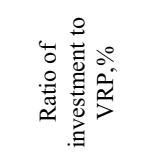 & 20 & 40.6 & $\begin{array}{c}19 . \\
4\end{array}$ & 19.0 & 36.6 & 30.7 & 31.1 & 22.1 & 23.0 & 29.8 & 24.8 & $\begin{array}{l}m \\
n \\
i \\
1 \\
0 \\
⿱ 1 \\
z \\
z\end{array}$ \\
\hline 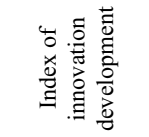 & $\begin{array}{c}0.21 \\
85\end{array}$ & 0.3728 & $\begin{array}{c}0.2 \\
755\end{array}$ & $\begin{array}{c}0.53 \\
82\end{array}$ & $\begin{array}{c}0.38 \\
07\end{array}$ & $\begin{array}{c}0.317 \\
1\end{array}$ & $\begin{array}{c}0.23 \\
24\end{array}$ & 0.3124 & $\begin{array}{c}0.35 \\
58\end{array}$ & $\begin{array}{c}0.31 \\
63\end{array}$ & $\begin{array}{c}0.287 \\
1\end{array}$ & $\begin{array}{l}\hat{N} \\
\text { Na } \\
\vdots \\
\frac{1}{\simeq}\end{array}$ \\
\hline 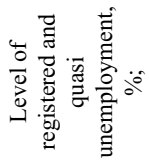 & $8-10$ & 8.1 & 6 & 1.5 & 4.5 & 7.3 & 6.5 & 5.6 & 6.7 & 3.7 & 5.4 & 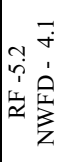 \\
\hline
\end{tabular}




\begin{tabular}{|c|c|c|c|c|c|c|c|c|c|c|c|c|}
\hline 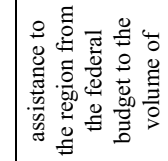 & 0.5 & 0.11 & $\begin{array}{c}0.3 \\
4\end{array}$ & 0.07 & 0.11 & 0.23 & 0.41 & 0.18 & 0.14 & 0.19 & 0.35 & 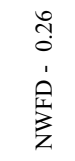 \\
\hline 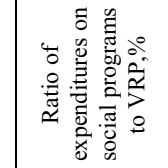 & 20 & 11 & $\begin{array}{c}16 . \\
2\end{array}$ & 10.5 & 9 & 32.5 & 18 & 11 & 16.8 & 11 & 11.9 & $\begin{array}{l}\infty^{\infty} \\
\dot{ \pm} \\
\dot{1} \\
\sum_{z}^{1} \\
z\end{array}$ \\
\hline 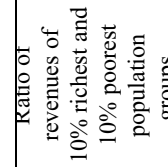 & 10:1 & $16.6: 1$ & $\begin{array}{l}11 . \\
3: 1\end{array}$ & $\begin{array}{c}20.2 \\
: 1\end{array}$ & 13:1 & $\begin{array}{c}\text { 12.4: } \\
1\end{array}$ & $\begin{array}{c}11.5: \\
1\end{array}$ & $12.1: 1$ & $14: 1$ & $\begin{array}{c}\text { 14.1: } \\
1\end{array}$ & $\begin{array}{c}12.9: \\
1\end{array}$ & 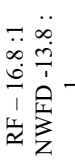 \\
\hline 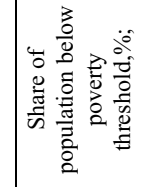 & 10 & 14 & 15 & 8.3 & 11 & 14.1 & 16.9 & 13.1 & 11 & 13 & 12.3 & $\begin{array}{l}\stackrel{a}{i} \\
\stackrel{1}{i} \\
\frac{1}{z}\end{array}$ \\
\hline 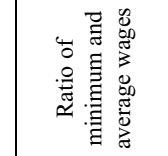 & $1: 3$ & $1: 6$ & $1: 5$ & $\begin{array}{c}1 \\
: 4.3\end{array}$ & $\begin{array}{l}1: \\
4.2\end{array}$ & $1: 6$ & $1: 3.5$ & $1: 4.5$ & $1: 3.6$ & $1: 4.2$ & $1: 3.2$ & 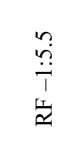 \\
\hline 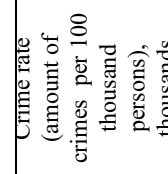 & $5-6$ & 2.377 & $\begin{array}{l}1.9 \\
95\end{array}$ & $\begin{array}{c}1.10 \\
0\end{array}$ & $\begin{array}{c}1.10 \\
5\end{array}$ & 1.655 & $\begin{array}{c}1.35 \\
2\end{array}$ & 2.050 & $\begin{array}{c}1.67 \\
1\end{array}$ & $\begin{array}{c}2.06 \\
0\end{array}$ & 1.617 & 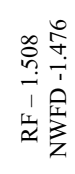 \\
\hline 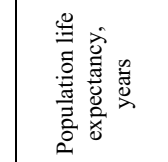 & $\begin{array}{l}65- \\
70\end{array}$ & 68.9 & $\begin{array}{c}68 . \\
4\end{array}$ & 74.1 & 70.4 & 70.3 & 67.2 & 69.8 & 70.5 & 68.4 & 70.8 & 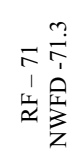 \\
\hline 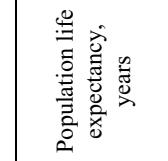 & $\begin{array}{l}65- \\
70\end{array}$ & 68.9 & $\begin{array}{c}68 . \\
4\end{array}$ & 74.1 & 70.4 & 70.3 & 67.2 & 69.8 & 70.5 & 68.4 & 70.8 & 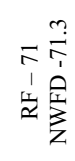 \\
\hline
\end{tabular}

Effective use of the economic potential of the North-West Federal District regions it is presented in Table 2 
Table 2. Effective use of the economic potential of the North-West Federal District regions.

\begin{tabular}{|c|c|c|c|c|c|c|c|c|}
\hline $\begin{array}{c}\text { Territorial units of } \\
\text { the Russian } \\
\text { federation }\end{array}$ & $\begin{array}{c}\text { Return } \\
\text { on } \\
\text { investme } \\
\text { nt, rub }\end{array}$ & $\begin{array}{c}\text { Return } \\
\text { on } \\
\text { assets, } \\
\text { rub }\end{array}$ & $\begin{array}{c}\text { Profi } \\
\text { tabili } \\
\text { ty of } \\
\text { capit } \\
\text { al } \\
\text { asset } \\
\text { s, } \%\end{array}$ & $\begin{array}{c}\text { Capital- } \\
\text { labor } \\
\text { ratio, mln } \\
\text { rub/per } \\
\text { capita }\end{array}$ & $\begin{array}{c}\text { Return } \\
\text { on } \\
\text { taxes, } \\
\text { kop }\end{array}$ & $\begin{array}{c}\text { Produc } \\
\text { tivity, } \\
\text { mln.ru } \\
\text { b }\end{array}$ & $\begin{array}{c}\text { Return } \\
\text { on } \\
\text { wages } \\
\text { rub }\end{array}$ & $\begin{array}{c}\text { Return } \\
\text { on } \\
\text { amorti } \\
\text { zation, } \\
\text { rub. }\end{array}$ \\
\hline $\begin{array}{c}\text { The Republic of } \\
\text { Karelia }\end{array}$ & 5.87 & 0.36 & 2.43 & 1.61 & 11.43 & 0.59 & 1.77 & 0.84 \\
\hline $\begin{array}{c}\text { The Komi Republic } \\
\text { The Arkhangelsk } \\
\text { Region }\end{array}$ & 3.02 & 0.25 & 3.3 & 4.35 & 24.51 & 1.1 & 2.44 & 0.55 \\
\hline $\begin{array}{c}\text { The Vologda } \\
\text { Region }\end{array}$ & 5.77 & 0.28 & 1.19 & 2.15 & 11.78 & 0.59 & 1.96 & 0.64 \\
\hline $\begin{array}{c}\text { The Kaliningrad } \\
\text { Region }\end{array}$ & 4.28 & 1.05 & 4.8 & 0.55 & 30.3 & 0.58 & 1.93 & 3.02 \\
\hline $\begin{array}{c}\text { The Leningrad } \\
\text { Region }\end{array}$ & 2.94 & 0.3 & 3.88 & 3.03 & 24.28 & 0.92 & 2.62 & 0.94 \\
\hline $\begin{array}{c}\text { The Murmansk } \\
\text { Region }\end{array}$ & 4.98 & 0.21 & 2.71 & 3.42 & 16.2 & 0.73 & 1.52 & 0.54 \\
\hline $\begin{array}{c}\text { The Novgorod } \\
\text { Region }\end{array}$ & 3.38 & 0.45 & 2.25 & 1.27 & 12.28 & 0.57 & 2.04 & 1.03 \\
\hline The Pskov Region & 4.19 & 0.36 & 0.77 & 0.98 & 13.82 & 0.35 & 1.48 & 0.89 \\
\hline $\begin{array}{c}\text { Saint-Petersburg } \\
\text { The }\end{array}$ & 6.8 & 0.57 & 8.57 & 1.69 & 22.62 & 0.97 & 2.2 & 1.56 \\
\hline
\end{tabular}

Source: the table is prepared on the basis of the data "Social and economic situation in the federal districts" - 2013 [12].

\section{References}

1. I.E. Denezhkina, D.A. Suzdaleva Effective crisis management, 10, 1-8 (2012)

2. Report on effectiveness complex assessment of the executive bodies of the territorial units of the Russian Federation by the end of 2013 (Ministry of regional development, Moscow, 2013)

3. E.S. Ivleva, Modernization of the Russian economy: forecasts and reality: Collection of papers of the international scientific and practical conference on 25th of March 2015, 96-100 (2015)

4. J. Fiksel, Design for Environment: Creating eco-efficient products and processes (McGraw - Hill Companies, 1996)

5. I. Kalinkova, Magazine "Expert North-West", 15(662), 3-6 (2014)

6. J. Kirshner, Review of International Political Economy, 5(1), 64 - 91 (1998)

7. Kh.S. Pakh, Journal of Vlast i upravlenie na Vostoke Rossii, 2, 42 - 47 (2012)

8. Information on http:www.complexdoc.ru

9. Information on http://gov.spb.ru/static/writable/documents/2014/04/24/

10. Information on http://www.gks.ru/bgd/regl/b13_20/Main.htm (2014).

11. A.D. Ursul, Journal Bezopasnost' Evrazii, 1, 443-456 (2001)

12. Information on http://gtmarket.ru/news/2014/03/13/6628 (march 13, 2014).

13. L.G. Vorona-Slivinskaia, Kh. S. Pak, Journal Problemi upravleniya riskami v tekhnosfere, 1, 119 -124 (2015)

14. N.V. Zubarevich, E.A. Gordina Sozialnie rashody v Rossii: federalnii i regionalnie budzheti, Information on http//csils.hse.ru/2015. 
15. A. Gorshkov, V. Murgul, O. Oliynyk, MATEC Web of Conferences, 53, Article number 01045 (2016)

16. V. Murgul, Procedia Engineering, 117, 808-818 (2015)

17. G. Radovic, V. Murgul, N. Vatin, Applied Mechanics and Materials, 641-642, 634638 (2014)

18. V.V Okrepilov, Ivanova, G. Standarty i Kachestvo, 12, 62-68. (2004)

19. V.V Okrepilov, Standarty i Kachestvo, 3, 94-96. (2003)

20. J. Ćetković, M. Knežević, M. Žarković, V. Murgul, N. Vatin, Applied Mechanics and Materials, 638-640, 2465-2470 (2014)

21. V.V Okrepilov, A.Yu. Smirnov, Measurement Techniques, 56(1), 54-60 (2013)

22. V.V Okrepilov, Studies on Russian Economic Development, 24(1), 35-42 (2013)

23. V.V Okrepilov, Standarty i Kachestvo, 10, 52-55 (2005) 